\title{
COVID-19-induced sarcopenia and physical deconditioning may require reassessment of surgical risk for patients with cancer
}

\author{
Patrick Casey ${ }^{*}$ (D), Yeng Ang and Javed Sultan
}

\begin{abstract}
Background: The long-term physiological consequences of SARS-CoV-2 (severe acute respiratory syndrome coronavirus) infection are not known. The ability of COVID-19 to cause chronic illness, sarcopenia, and physical deconditioning may be underestimated and go beyond the anticipated respiratory sequelae. Myalgia, lethargy, and anorexia are common symptoms even in mild to moderate cases and have the potential to exacerbate frailty. How this impacts on risk-stratification for patients requiring surgery for time-critical conditions, such as malignancy, requires further urgent investigation.

Main body: The deleterious effect of sarcopenia and poor physical capacity are well recognised in cancer surgery. This review commentary highlights current evidence which suggests skeletal muscle as an under recognised cause of COVID-19-related functional deconditioning. The mechanisms behind this are via direct (viral induced myositis, nutritional decline, cytokine-mediated myopathy) and indirect mechanisms (social isolation, inactivity, and psychological consequences).
\end{abstract}

Conclusion: Further mechanistic research is required to explore the processes behind the deconditioning effects of SARS-COV-2 infection and how this impacts on treatment of malignant disease.

Keywords: COVID-19, SARS-CoV-2, Functional deconditioning, Sarcopenia, Frailty, Prehabilitation

\section{Main text}

High-quality clinical trials are making great strides in the treatment of acute SARS-CoV-2 infection whilst the research world adjusts its focus on long-term consequences of the disease. The term 'long COVID' is gaining popularity in the literature and denotes a multisystem deconditioning with symptoms lasting weeks if not months. Surgical teams are encountering increasing numbers of patients who have survived COVID-19. Whilst most patients will fully recover from the illness, some will be left with lasting symptoms and the impact on perioperative risk is currently unknown.

\footnotetext{
* Correspondence: Patrick.casey@srft.nhs.uk

Department of Oeosphagogastric Surgery, Salford Royal Foundation Trust, Salford, UK
}

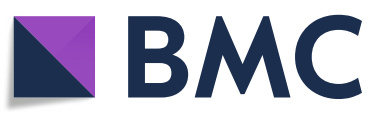

(c) The Author(s). 2021 Open Access This article is licensed under a Creative Commons Attribution 4.0 International License, which permits use, sharing, adaptation, distribution and reproduction in any medium or format, as long as you give appropriate credit to the original author(s) and the source, provide a link to the Creative Commons licence, and indicate if changes were made. The images or other third party material in this article are included in the article's Creative Commons licence, unless indicated otherwise in a credit line to the material. If material is not included in the article's Creative Commons licence and your intended use is not permitted by statutory regulation or exceeds the permitted use, you will need to obtain permission directly from the copyright holder. To view a copy of this licence, visit http://creativecommons.org/licenses/by/4.0/ The Creative Commons Public Domain Dedication waiver (http://creativecommons.org/publicdomain/zero/1.0/) applies to the data made available in this article, unless otherwise stated in a credit line to the data. 
cardiopulmonary exercise testing (CPET) and spirometry are discouraged due to their aerosol risk.

Anorexia, anosmia, and weight loss are also common features of SARS-CoV-2 infection and may exacerbate nutritional deficits and muscle wasting already seen in patients with active malignancy. Some patients may never recover to their baseline functional capacity [810]. It is clear that those severely affected by COVID-19 with prolonged convalescence should have cancer surgery delayed where possible. Multimodal prehabilitation and rehabilitation may help to avoid lasting morbidity and reduce perioperative risk [11]. Data is lacking, however, on the deconditioning effects for patients with mild or moderate disease who are treated in the community. Any mild illness with even short periods of inactivity could see skeletal muscle loss of $0.5-6 \%$ per day [12]. Patients operated on with asymptomatic COVID-19 had increased risk of perioperative morbidity and mortality. Doglietto et al. showed that 30-day risk of mortality was significantly higher $19.5 \%$ vs $2.4 \%$; OR 9.5, CI $1.8-96.5$ ) compared to patient without COVID-19 [13]. As surgeons and oncologists across the world adjust pathways to safely offer treatment for malignant disease, the results from the GlobalSurg-CovidSurg Week study are eagerly anticipated. This international collaborative observational study aims to determine the optimal timing for surgery following SARS-CoV-2 infection. Early signals from around 150 patients show that pre-operative diagnosis of SARS-CoV-2 is associated with poorer peri-operative outcomes even in those who were diagnosed several weeks prior to surgery [14]. The underlying reasons for this remain unclear but could be related to sarcopenia and physical deconditioning following COVID-19. The results of their study will better inform surgical decision-making and identify patient groups that will benefit from multimodal rehabilitation (or prehabilitation).

\section{Skeletal muscle as a potential target}

Both muscle weakness and myalgia are well recognised in COVID-19 [15]. Studies of hospitalised patients have described biochemical evidence of muscle damage [16]. Several reports of severe rhabdomyolysis, even in the absence of respiratory symptoms, suggests skeletal muscle tissue is not immune from the disease process [17-19]. Virus-induced myositis is seen with other pathogens including SARS-CoV-1 and influenza but is unclear whether immune-mediated injury due to myotoxic cytokines (such as CXCL-10, IFN- $\Upsilon$, IL-1 $\beta$, IL-6, IL-17, and TNF $\alpha$ ) or if direct viral infiltration is the predominant pathological process. SARS-CoV-2 viral particles have been detected by electron microscopy within skeletal muscle and cardiac muscle fibres whilst distressing case reports of fatal cardiac failure in children due to fulminant cardiomyopathy suggests the direct impact on muscle tissue can be profound [20]. SARS-CoV-2 enters host cells via the angiotensin-converting enzyme 2 (ACE2) receptor. Both skeletal and cardiac muscle exhibit robust expression on the ACE2 receptor on their surface as do many other tissues offering a potential viral route for direct tissue damage [21, 22]. Clinical parallels can be drawn from the SARS-CoV-1 pandemic in 2003 owing to its genetic and clinicopathological homology with SARS-CoV-2. Extensive myalgia and muscle dysfunction were reported in SARS patients. Widespread muscle fibre atrophy, fibre necrosis, myofibril disarray, and Z-disc streaming was demonstrated in post-mortem muscle tissue [23]. Furthermore, relatively fit SARS survivors were shown to have objective reductions in hand grip strength (32\%) and 6-min walk test (13\%) when followed up in clinic [24]. Similar functional outcomes measures in survivors of COVID-19 have also been described with measurable reductions in indices of muscle strength and physical function [25]. How long these impairment last for is unknown.

The indirect ability of the viral pandemic to cause physical deconditioning should also be considered. Some experts predict a pandemic-related increase in surgical morbidity and mortality due to social isolation and reduced activity levels in patients, where operations have been rescheduled or postponed [26, 27]. This deleterious effect will be more striking in the elderly or medically frail who also suffer psychological consequences and demotivation. For patients awaiting major cancer surgery, many community prehabilitation programs and local gymnasiums have closed evoking a rapid response to establish at-home exercise programs and telemedicine to minimise the effects of social isolation and preoperative inactivity.

In conclusion, the ability of SARS-CoV-19 to cause physical decline is multifactorial and may be related to periods of convalescence, reduced appetite, chronic cardiorespiratory symptoms, social isolation, and reduced access to physical activity (Fig. 1). The direct and indirect impact on muscle strength, sarcopenia, and frailty may be underestimated and could, in part, explain the poor surgical outcomes seen in patients with previous SARS-CoV-2 infection. Functional outcome scales such as those proposed by Klok et al. may compliment standard assessment tools such as WHO performance status in assessing global functional recovery from the illness but remain unvalidated [28]. Pragmatic approaches to keep physically active prior to cancer surgery, such as home-based exercise programs, will become increasingly important as well as novel rehabilitation techniques for those worse effected by COVID-19 [29]. Going forward, we need a better understanding on how, and to what 


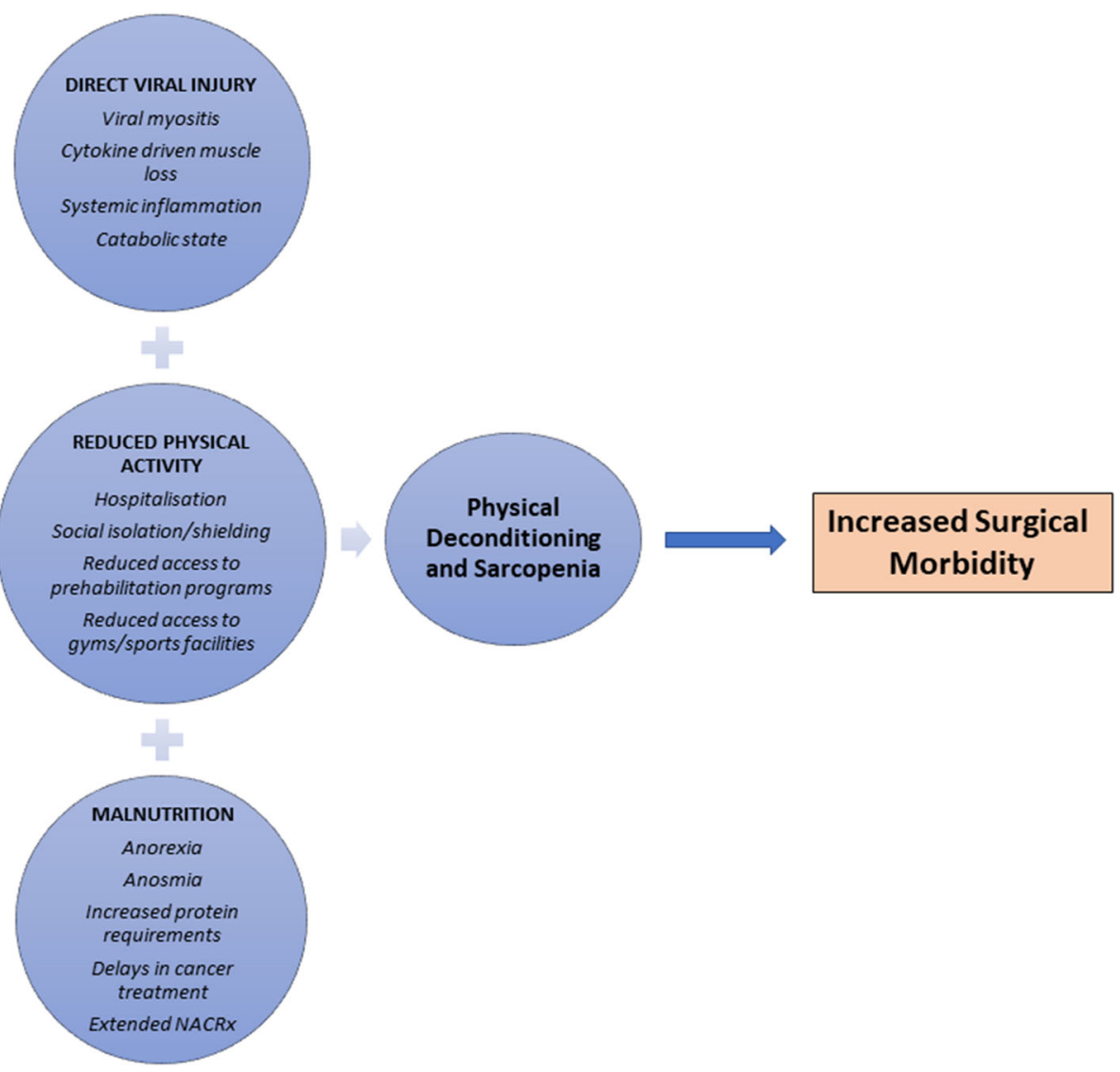

Fig. 1 Schematic of proposed mechanisms causing deterioration in physical function and sarcopenia in patients requiring cancer surgery. Multimodal prehabilitation for COVID survivors may be required to overcome these factors. NACRx, neoadjuvant chemoradiotherapy

degree, COVID-19 causes physical deconditioning in mild, moderate, and severe cases alike. Whether this adjusts peri-operative risk for patients requiring cancer surgery requires further investigation to identify best timing for surgery and to tailor focussed prehabilitation for COVID-19 survivors.

\section{Acknowledgements}

No specific acknowledgements.

\section{Authors' contributions}

PC-literature review, manuscript production, and revision. YA—literature review, manuscript edit, and revision. JS—review concept, literature review, manuscript edit, and revision. All authors contributed equally and approved the final draft of the manuscript.

\section{Funding}

The authors received no funding source in the production of this article.

\section{Availability of data and materials}

All data and materials used in the production of this work will be available on request.

\section{Ethics approval and consent to participate}

No specific ethical approval required for the production of this review article.

\section{Consent for publication}

All contributors give consent for unrestricted publication of this work.

\section{Competing interests}

The authors have no competing interests to declare.

Received: 20 October 2020 Accepted: 28 December 2020

Published online: 11 January 2021

\section{References}

1. Greenhalgh T, Knight M, A'Court C, Buxton M, Husain L. Management of post-acute covid-19 in primary care. BMJ. 2020;370:m3026. https://doi.org/ 10.1136/bmj.m3026.

2. Nasiri MJ, Haddadi S, Tahvildari A, et al. COVID-19 clinical characteristics, and sex-specific risk of mortality: Systematic Review and Meta-analysis. medRxiv. 2020:2020.03.24.20042903. https://doi.org/10.1101/2020.03.24.20042903.

3. Heydari K, Rismantab S, Shamshirian A, et al. Clinical and paraclinical characteristics of covid-19 patients: a systematic review and meta-analysis. medRxiv. 2020:2020.03.26.20044057. https://doi.org/10.1101/2020.03.26. 20044057.

4. Garner P. Paul Garner: For 7 weeks I have been through a roller coaster of ill health, extreme emotions, and utter exhaustion: BMJ Publishing Group: 2020. https://blogs.bmj.com/bmj/2020/05/05/paul-garner-people-who-havea-more-protracted-illness-need-help-to-understand-and-cope-with-theconstantly-shifting-bizarre-symptoms/.

5. Arnold DT, Hamilton FW, Milne A, et al. Patient outcomes after hospitalisation with COVID-19 and implications for follow-up; results from a prospective UK cohort. medRxiv. 2020:2020.08.12.20173526. https://doi.org/ 10.1101/2020.08.12.20173526.

6. Carfi A, Bernabei R, Landi F. Group for the GAC-19 P-ACS. Persistent symptoms in patients after acute COVID-19. JAMA. 2020;324(6):603-5. https://doi.org/10.1001/jama.2020.12603. 
7. Pipek LZ, Baptista CG, Nascimento RFV, et al. The impact of properly diagnosed sarcopenia on postoperative outcomes after gastrointestinal surgery: A systematic review and meta-analysis. PLoS One. 2020;15(8): e0237740. https://doi.org/10.1371/journal.pone.0237740.

8. Tu H, Tu S, Gao S, Shao A, Sheng J. Current epidemiological and clinical features of COVID-19; a global perspective from China. J Infect. 2020;81(1):19. https://doi.org/10.1016/j.jinf.2020.04.011.

9. Lippi G, Wong J, Henry BM. Myalgia may not be associated with severity of coronavirus disease 2019 (COVID-19). World J Emerg Med. 2020;11(3):193-4. https://doi.org/10.5847/wjem.j.1920-8642.2020.03.013.

10. Huang C, Wang Y, Li X, et al. Clinical features of patients infected with 2019 novel coronavirus in Wuhan, China. Lancet. 2020;395(10223):497-506. https://doi.org/10.1016/S0140-6736(20)30183-5.

11. Li J. Rehabilitation management of patients with COVID-19: lessons learned from the first experience in China. Eur J Phys Rehabil Med. 2020;56(3):335-8. https://doi.org/10.23736/s1973-9087.20.06292-9.

12. Kortebein P, Frontera W, DeLisa J, JR B. Physical inactivity: physiologic impairments and related clinical conditions. In: Delisa's physical medicine and rehabilitation: principals and practice. Philadelphia, PA: Lippincott Williams \& Wilkins; 2019.

13. Doglietto F, Vezzoli M, Gheza F, et al. Factors associated with surgical mortality and complications among patients with and without coronavirus disease 2019 (COVID-19) in Italy. JAMA Surg. 2020;155(8):691-702. https://doi. org/10.1001/jamasurg.2020.2713.

14. COVIDSurgCollaborative. GlobalSurg-CovidSurg week: determining the optimum timing for surgery following SARS-CoV-2 infection. https:// globalsurg.org/globalsurg-covidsurg-week/. Published 2020.

15. Carod-Artal FJ. Neurological complications of coronavirus and COVID-19. Rev Neurol. 2020;70(9):311-22. https://doi.org/10.33588/rn.7009.2020179.

16. Mao $L$, Jin $H$, Wang $M$, et al. Neurologic manifestations of hospitalized patients with coronavirus disease 2019 in Wuhan, China. JAMA Neurol. 2020; 77(6):683-90. https://doi.org/10.1001/jamaneurol.2020.1127.

17. Jin $\mathrm{M}$, Tong Q. Rhabdomyolysis as potential late complication associated with COVID-19. Emerg Infect Dis. 2020;26(7):1618-20. https://doi.org/10.3201/ eid2607.200445

18. Borku Uysal B, Ikitimur H, Yavuzer S, Islamoglu MS, Cengiz M. Case report: a COVID-19 patient presenting with mild rhabdomyolysis. Am J Trop Med Hyg. 2020;103(2):847-50. https://doi.org/10.4269/ajtmh.20-0583.

19. Zhang Q, Shan KS, Minalyan A. A rare presentation of coronavirus disease 2019 (COVID-19) induced viral myositis with subsequent rhabdomyolysis. Cureus. 2020;12(5):e8074. https://www.cureus.com/articles/31422-a-rarepresentation-of-coronavirus-disease-2019-covid-19-induced-viral-myositiswith-subsequent-rhabdomyolysis.

20. Dolhnikoff M, Ferreira Ferranti J, de Almeida Monteiro RA, et al. SARS-CoV-2 in cardiac tissue of a child with COVID-19-related multisystem inflammatory syndrome. Lancet Child Adolesc Heal. 2020;0(0). https://doi.org/10.1016/ S2352-4642(20)30257-1.

21. Ferrandi PJ, Alway SE, Mohamed JS. The interaction between SARS-CoV-2 and ACE2 may have consequences for skeletal muscle viral susceptibility and myopathies. J App/ Physiol. 2020. https://doi.org/10.1152/japplphysiol. 00321.2020.

22. Disser NP, De Micheli AJ, Schonk MM, et al. Musculoskeletal consequences of COVID-19. JBJS. 2020;102(14):1197-1204. https://journals. Iww.com/jbjsjournal/Fulltext/2020/07150/Musculoskeletal_Consequences_ of_COVID_19.1.aspx.

23. Leung TW, Wong KS, Hui AC, et al. Myopathic changes associated with severe acute respiratory syndrome: a postmortem case series. Arch Neurol. 2005;62(7):1113-7. https://doi.org/10.1001/archneur.62.7.1113.

24. Lau HM-C, Lee EW-C, Wong CN-C, Ng GY-F, Jones AY-M, Hui DS-C. The impact of severe acute respiratory syndrome on the physical profile and quality of life. Arch Phys Med Rehabil. 2005;86(6):1134-40. https://doi.org/10. 1016/j.apmr.2004.09.025.

25. Paneroni M, Simonelli C, Saleri M, et al. Muscle strength and physical performance in patients without previous disabilities recovering from COVID-19 pneumonia. Am J Phys Med \&amp; Rehabil. 2020. https://doi.org/ 10.1097/phm.0000000000001641.

26. Silver JK. Prehabilitation may help mitigate an increase in COVID-19 peripandemic surgical morbidity and mortality. Am J Phys Med Rehabil. 2020;99(6):459-63. https://doi.org/10.1097/PHM.0000000000001452.

27. Silver JK. Prehabilitation could save lives in a pandemic. BMJ. 2020;369: m1386. https://doi.org/10.1136/bmj.m1386.
28. Klok FA, Boon GJAM, Barco S, et al. The post-COVID-19 functional status scale: a tool to measure functional status over time after COVID-19. Eur Respir J. 2020;56(1). https://doi.org/10.1183/13993003.01494-2020.

29. Nakamura K, Nakano H, Naraba H, Mochizuki M, Hashimoto H. Early rehabilitation with dedicated use of belt-type electrical muscle stimulation for severe COVID-19 patients. Crit Care. 2020;24(1):342. https://doi.org/10. 1186/s13054-020-03080-5.

\section{Publisher's Note}

Springer Nature remains neutral with regard to jurisdictional claims in published maps and institutional affiliations.
Ready to submit your research? Choose BMC and benefit from:

- fast, convenient online submission

- thorough peer review by experienced researchers in your field

- rapid publication on acceptance

- support for research data, including large and complex data types

- gold Open Access which fosters wider collaboration and increased citations

- maximum visibility for your research: over $100 \mathrm{M}$ website views per year

At BMC, research is always in progress.

Learn more biomedcentral.com/submissions 